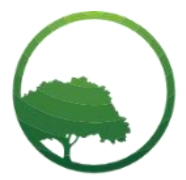

Business \& Social Science IJRBS

\section{Research in Business \& Social Science}

IJRBS VOL 9 NO 3 ISSN: 2147-4478

Available online at www.ssbfnet.com Journal homepage: https://www.ssbfnet.com/ojs/index.php/ijrbs

\title{
Economic approach in corruption settlement based on state loss value
}

\author{
Samsul Huda@(a), Prija Djatmika@(b), Bambang Sugiri@ (c), Siti Hamidah@ (d) \\ Crossref
}

(a,b,c,d)Faculty of Law, Brawijaya University, Malang, Indonesia

\begin{tabular}{l} 
A R T I C L E I N F O \\
\hline Article history: \\
Received 23 March 20 \\
Received in revised form 15 April 20 \\
Accepted 27 April 20 \\
\hline Keywords: \\
Corruption, law enforcement, state \\
loss, economic approach \\
JEL Classification: \\
K14, K23, K34
\end{tabular}

\begin{abstract}
A B S T R A C T
The purpose of this research is to find out how to resolve corruption on the basis of the value of state loss with an economic approach to the law. This research is normative juridical research with a statute approach, comparative approach, case approach and conceptual approach. This research shows research on the philosophy of eradicating corruption, restoring state losses, and high efficiency in order to realize economic growth and national development through an economic analysis approach to the application of its law. The results showed that the PTPK Law was made for economic stability, therefore, solving the problem of corruption cannot be separated from the consideration of the country's economy, and the costs that pose a relative risk to state expenditure affecting the country's economy. The juridical reality, the regulation of additional criminal charges, namely the penalty of paying as much as the amount of corrupt compensation as stated in Article 18 paragraph 1 letter $(b)$ of the PTPK Law, if it is related to empirical facts about the imbalance between costs and the recovered economic value, is the reality is that the series of state expenses have increased.
\end{abstract}

(C) 2020 by the authors. Licensee SSBFNET, Istanbul, Turkey. This article is an open access article distributed under the terms and conditions of the Creative Commons Attribution (CC BY) license (http://creativecommons.org/licenses/by/4.0/).

\section{Introduction}

Promoting public welfare is a constitutional mandate. General welfare can be achieved through the implementation of good governance (the principles of good administration) and good financial governance (the principles of good financial governance). The implementation is (1) the effectiveness of activities, (2) financial efficiency, (3) increasing the role of the control function, (4) stabilizing the economy through optimization of the financial function, and; (5) financial management according to basic principles, general principles, and statutory regulations.

Legislation is formed to stimulate behavior in the direction the state expects. For example, the outcomes aimed at general criminal law are to create social order, while the outcomes aimed at criminal law on corruption are to (1) eradicate corruption, recover state losses, and (3) high efficiency in order to realize economic growth and national development. Despite differences in outcomes, law enforcement is an action that is believed to have a sustainable effect in the future (presidenri.go.id). That is, the frame for implementing law enforcement is prepared by considering (1) the purpose of making law, (2) the benefits of law enforcement itself; and (3) their influence on the perpetrators and the community. Paying close attention to the legal politics of the PTPK Law, which tends to contribute to the economic contribution, law enforcement against corruption does not merely imprison the perpetrators but rather to maintain the value that the PTPK Law intends to protect, namely the eradication of corruption, and the return of state losses, to create high efficiency in order to achieve growth national economy and development. The output is general welfare.

In reality, the practice of law enforcement (punishment) has not had an effect on improving morality and corruption is growing more widespread, the state loss is not fully recovered and there is a tendency for leakage of state money in the law enforcement sector because the value of the loss saved is smaller than the economic value of the state's own economy lost. The impact is not created high efficiency for economic growth and national development, but rather adds to the burden of state expenditure that does not contribute to the state (Louis \& Steven, 2002). The use of the budget is an inseparable part of the country's economic value. Even though Article 4 of the PTPK Law states that returning a state loss does not eliminate criminal penalties, the use of its law enforcement budget must be as efficient and economical as article 3 of the State Loss (KN) Law, so as not to be inconsistent with Article 23

* Corresponding author. ORCID ID: 0000-0002-2279-5196

(C) 2020 by the authors. Hosting by SSBFNET. Peer review under responsibility of Center for Strategic Studies in Business and Finance.

https://doi.org/10.20525/ijrbs.v9i3.674 
paragraph (1) of the 1945 NRI Constitution the 3rd amendment, Article $3 \mathrm{KN}$ Law, Article 5 paragraph (3) and Article 30 paragraph (3) Law No. 7 of 2006 concerning Ratification of the United Nations Convention Against Corruption, 2003, Presidential Decree No. 54 of 2018 concerning the National Strategy for Corruption Prevention and 7th Instruction Instruction No 5 of 2004 concerning the Acceleration of Corruption Eradication.

The reality of inconsistency encourages the need to do a review of the limits of the use of criminal law with a test to reduce its economic value through rationality, effectiveness, efficiency, utilities, and transaction costs (john, 2017) so that it does not potentially cause leakage of state finances (The 9th Directive Inpres No. 5 of 2004). The effectiveness and efficiency of law enforcement transaction costs should not merely consider instrumental theory and criminal law policy theory (Nazaruddin, 2017). The "economic analysis of the law" approach is important and is needed to maximize the effectiveness of the law to prevent corruption in the law enforcement sector. Based on the background that has been explained above, the purpose in this paper is first to find out how the settlement of corruption on the basis of state loss value with an economic approach to the law.

\section{Literature Review}

\section{The nature of the economic approach to law}

Law is an inseparable part of national economic growth and development policies. If economic units are able to achieve prosperity, then prosperity will generally be realized (Hunt, 1986). Justice, certainty, expediency, confrontation, order, peace are only alternative objectives. The following is the linkage between law and economics in realizing national development:

- $\quad$ Economics is the research of how individuals and society make choices about the use of scarce resources that have been provided by nature and previous generations(Gunawan, 2018), whereas the science of law studies how the actual position of the law in society, how the relationship or association between law with other sub-systems in society, such as politics, economics and so on. In essence, the law regulates the behavior of economic agents towards order so as to achieve a balance in social life;

- The function of law is as one of the variables in an effort to create balance through the regulation and protection of the behavior of individuals in meeting the needs of life, while the economic function as a variable meets the needs for the achievement of prosperity and prosperity.

- $\quad$ The role of law and economics in national development is to create a balance in meeting the needs of the economy through the integration of the functions of economics and law.

- The legal and economic position in development as a stabilizer of basic values that already exist and live in society. In dealing with social, legal and economic problems with its flexibility to correlate to be able to provide maximum benefits in improving welfare and prosperity.

\section{Corruption Crime Countermeasures in the Research Meet the Indicators of Rationality}

Suparmoko (1992) state that if corruption is said to be a moral crime, in fact many a-moral acts such as theft, embezzlement, fraud but do not constitute a crime of corruption. If some of the factors of corruption are a-moral acts, it implies that there are moral acts of corruption. From the implicit meaning contained in the PTPK Law and related realities that occur in the field, it illustrates that corruption is not synonymous with moral crime, but there are criteria for actions that are agreed upon and decided to be criminalized, then stated in the PTPK Law as acts called corruption. Then what about the concept of criminalization of the PTPK Law in relation to the flow of law regarding the concept of punishment? Answering this question needs to first review the PTPK Law from the point of view of the substance of sanctions. The formulation of double track punishment in the PTPK Law implicitly presents two concepts of punishment namely (Romli, 2018):

- Criminalization for detention purposes.

The concept of punishment as a form of deterrence positions the law as an instrument of retaliation so that the perpetrators become deterrent. The length of imprisonment or confinement does not guarantee a deterrent effect, unless there is no longer an economic value that benefits the offender. The deterrence point is a balance point between the profits of the offender and the punishment received.

- $\quad$ Penalties for the purpose of restoring state losses.

The concept of punishment for the recovery of state losses puts the law in the nature as an obligation of actors to recover state losses in order to realize high efficiency in the context of economic growth and national development (ET PEPN). Law enforcement against perpetrators of corruption with an orientation to prioritize criminal prosecution without regard to costs and recovery of state losses is not in line with the basic norms of establishing the PTPK Law and will sacrifice the benefit of the people's interests, namely ET PEPN. If we examine more deeply on the standards of good and bad state administrators in managing state finances, then the reference/parameter of good measurement lies in the basic principles and general principles of management of state finances as article 3 of the KN Law. 
Noting the above views, it was found that the substance of Indonesian legal products did not entirely punish on the basis of an assessment of morality. The PTPK Law penalizes eradicating corruption in the context of bringing about economic stability through Recovery Of State Losses (PKN) and ET PEPN (Sadono, 2009). Implementation of corruption prevention must reduce economic fundamentals, as follows:

\section{Rationality}

The rationality in tackling corruption is a logical assessment of the desire to realize the objectives of the PTPK Law, namely the eradication of corruption because it harms the state, Recovery Of State Losses (PKN) and ET PEPN. The balance point between the concept of punishment for entrapment with Recovery Of State Losses (PKN) and ET PEPN can be illustrated in the following graph:

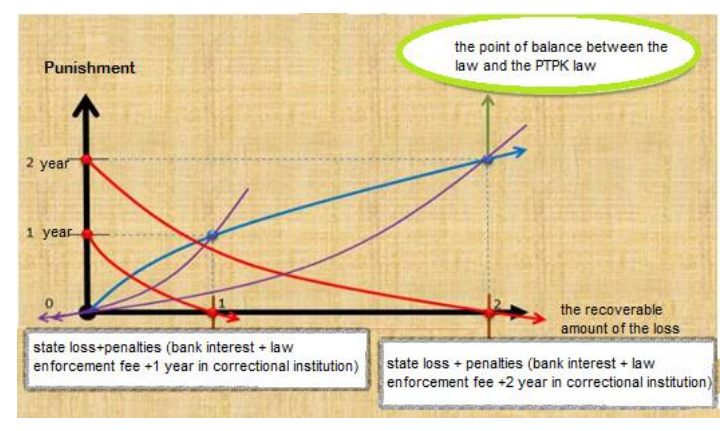

Fig.1: Corruption Crime and Recovery of Loss Value; Source: the results of research analysis by the authors.

The graph illustrates that imprisonment will benefit welfare through sustained economic growth, and the creation of efficient state spending the following year. When the perpetrators only serve prison sentences without recovering the lost economic value, law enforcement tends to harm the state. Conversely, if the perpetrator does not undergo a crime but only pays the recovery of the lost value plus a fine (the accumulation of maximum criminal costs in the economic calculation plus the economic value of the lost state property), the country will benefit economically. This is contrary to the philosophy of the PTPK Law because law enforcement is not for the purpose of seeking profit.

\section{Choice}

The problem of corruption demands that the PTPK Law be adaptive to the development of society. Regulations that implicitly take into account the potential losses and benefits in overcoming criminal acts of corruption, but do not reduce the economic concept, will not provide a legal solution unless it merely provides spaces of legal choice in combating corruption. The value of punishment must not be lacking in all cases what is sufficient to weigh the weight of the violation benefit (Gunawan, 2018).

Value

The economic value of law enforcement against corruption is the eradication of corruption so that the state does not lose, the state losses are recovered, the perpetrators are not profitable so that the deterrent, the results of loss recovery is useful to save state expenditure the following year. The non-use value of law enforcement on economic development, is the value of the educational effect of punishment that makes people not corrupt so as to create economic stability.

\section{Efficiency}

The efficiency of law enforcement against corruption is closely related to the use of the state budget. The measure of economic efficiency does not always take the form of using minimum costs to obtain maximum profits, but rather achieving economic value that can provide the intended welfare. Enforcement of the PTPK Law will be efficient if it contributes to the expectations of the country, and is able to influence the community to achieve economic goals namely maintaining economic stability and accelerating economic growth, the outcome of which is the achievement of prosperity.

\section{Utility}

The effect of the balance between deterrence, benefits, and justice in law enforcement against criminal acts of corruption is to minimize/prevent the occurrence of state losses in the context of efficiency in realizing economic growth and national development. If deterrence is identified with suffering, revenge, torture from the state (as a victim) against convicted of corruption, then the value of criminal benefit will be achieved if the essence of punishment is in line with the objective of establishing the PTPK Law.

\section{Game Theory}

Game strategies that can be implemented in dealing with corruption include the theory of Karl E. Case and Ray C. Fair, viz:

\section{A Dominant Strategy Game}


a) The game model one of the players chooses without knowing the strategy used by the opponent.

In this game, it is assumed that Law Enforcement Officials (APH) does not know the perpetrators' strategies in dealing with legal issues. The strategy game that APH can apply in the illustration is as follows:

- Circumstances where the perpetrator does not acknowledge his actions and do not show the results of his crime, while the APH does not pursue recognition from the perpetrators.

In this condition, APH uses a strategy to collect evidence of actions against the law, trace the assets of perpetrators kept in their names or on behalf of other parties conditioned by the perpetrators. If the perpetrators do not carry out additional criminal penalties in the form of paying replacement money, then the property can be confiscated by the Prosecutor and auctioned off to cover the replacement money. Thus the perpetrators do not get the benefit of corruption, so that the deterrence effect is achieved and the state's losses are recovered.

- Conditions where the perpetrator acknowledges his actions and submits the proceeds of his crime to be confiscated, whereas APH does not pursue confession.

Under these conditions, APH chose not to trust the perpetrators' recognition. The strategy adopted by APH is to collect evidence of irregularities resulting in state losses. This is to canalize the profit space for the perpetrators so that the strategies of the perpetrators to hide the proceeds of corruption crime can be revealed and the assets can be confiscated. The end result of the deterrence effect is achieved and the country does not suffer any more losses.

- Circumstances where the perpetrators did not admit their actions and did not want to show the results of the crime of corruption, while the APH implemented a strategy to pursue recognition.

In this condition, APH aggressively presses the perpetrators with evidence of acts against the perpetrators' law. The evidence is expected to find the value of economic losses arising from the perpetrators' actions, where he keeps the proceeds of his crimes, and the good faith of the perpetrators to return the state losses incurred. The weakness of this strategy is the less information about storing the proceeds of corruption crimes committed by the perpetrators, the greater the failure of the state loss recovery effort.

- The circumstances in which the APH perpetrators admit to their actions, want to show the results of the crime of corruption, and so the APH pursues recognition.

In this position both players have the same will so that there is the highest balance point. This condition can be said to be a comfort zone for both APH and perpetrators, but this comfort zone does not mean that the target of eradicating corruption, Recovery Of State Losses (PKN) and ET PEPN is because it is very possible for the perpetrators to hide a calculated benefit if the worst happens, namely to go to prison.

b) The game model of both players have a dominant strategy.

This game model can be illustrated by the APH accusing the perpetrators of corruption, but the nature of unlawful acts by the perpetrators is not strong. If forced into the criminal legal process, the perpetrators can be free and the use of the state budget for criminal proceedings does not contribute to the state, even though the perpetrators' actions have clearly caused state losses.

c) The one-player game model does not have a dominant strategy but the results can be predicted.

In this game model, it can be illustrated that APH does not have a strategy while the perpetrators have a strategy to break away from the bondage of law, but the direction can be predicted by APH. This situation brought APH into and followed the circle of perpetrators' games. APH's strategy is to maximize the evidence as a counter alibi for the offender so that the offender's strategy can be broken. The strong value of evidence against the perpetrators of law that is a factor causing the emergence of state losses automatically will also minimize the risk of perpetrators free from legal bondage and maximize recovery of state losses (PKN).

\section{Maximum Strategy Game}

This strategy is played with the illustration that the actor will choose to place himself at a disadvantage as an alternative to the smallest risk than the choice of other risks. Facing the perpetrators' strategy like this, APH must instead maximize the recovery of state losses by tracing the assets of the actors. The attitude of such actors has taken into account the benefits, and not the cooperative judgment in dealing with the legal process. The purpose of tracing the assets of the perpetrators is as an anticipatory step when the perpetrators in the next strategy do not carry out additional penalties in the form of paying compensation money. With their assets known, the APH (prosecutor) can confiscate and auction them off to fulfill the obligation of the offender to pay compensation. The loss of economic value derived from the proceeds of crime makes the perpetrators feel that corruption is not profitable. This text is a deterrent point, while the payment of compensation money in a fine is a form of restoration of state losses (Fajar, 2013).

\section{Mutual Strategy Game}

The game of mutual retaliation strategy can be illustrated in the state of APH and the perpetrators have equal power. APH has a dominant position with evidence of illegal acts committed by the perpetrators, while the perpetrators have power and strong influence 
that can intervene in the position of the APH. Conflicts of interest are very likely to arise in situations like this. Perpetrators will use their influence, or take refuge behind influential authorities, intervene in APH. The strong position of the APH in the evidence and the strength of the intervention of the perpetrators with influence and power, became the factors that pushed the two parties into the circle of the game strategy to reciprocate. APH and the perpetrators had the opportunity for collusion so that cooperative actors were present undergoing legal proceedings without detention.

\section{Transaction Costs}

Observing the morale of the PTPK Law contained in its philosophical background, the spirit of this Law is based on maintaining the stability of the country's economy so that its enforcement must take into account its economic level. The successful implementation of the PTPK Law can be viewed economically from the expectations of the results of government programs financed with the country's finances in the future. That is, costs arising from corruption prevention activities, which include investigative costs, investigation costs, prosecution fees and judicial examination fees and the costs of guiding prisoners in prison, at least the same as the expected point of economic value of the state lost.

Analysis of the economic level of law enforcement against corruption which has a loss value of less than Rp 50,000,000 (fifty million rupiah) in terms of rationality, choice, value, efficiency, utility, game theory and transaction costs

Through this research the authors analyze the effectiveness and efficiency of handling corruption according to its economic value, as follows:

The economic value of law enforcement is reached at the point of balance between the function of the PTPK Act (solving problems) and the effectiveness of the law (the effect of applying the PTPK Law). This value is calculated through the contribution (the value of the state loss recovered) is directly proportional to the relative risk (law enforcement costs). While the level of punishment for the body is calculated directly proportional to the amount of replacement money to be paid by the perpetrators. If the expenditure by the state is greater than the contribution of law enforcement, then law enforcement does not have economic value for the country, but rather adds to the financial burden of the state.

To explore the economic level of law enforcement against corruption which has a loss value of less than Rp. 50,000,000 (fifty million rupiah), the researcher raised several corruption cases that had received court decisions.

Table 1: Corruption with loss less than Rp 50.000.000,-

\begin{tabular}{|c|c|c|c|c|}
\hline No. & Case & State Losses & Decision Number & Fill in the Decision \\
\hline 1 & $\begin{array}{l}\text { Corruption ADD Krecek } \\
\text { Village Badas District, } \\
\text { Kediri Regency }\end{array}$ & Rp. 14.161.400,- & $\begin{array}{l}\text { 111/pK/Pid.sus/2003, } \\
\text { December 17, } 2014\end{array}$ & $\begin{array}{l}\text { Jail } 1 \text { year fine of } 50 \text { million } \\
\text { subsidiary } 1 \text { month confinement, pay } \\
\text { a replacement of Rp. } 4.245 .000 \text {, - } \\
\text { subsidiary of } 6 \text { months in prison }\end{array}$ \\
\hline 2 & $\begin{array}{l}\text { Corruption of Infrastructure } \\
\text { Funds and clean water } \\
\text { infrastructure facilities in } \\
\text { Keling Village, Kapung } \\
\text { District, Kediri Regency }\end{array}$ & Rp.32.000.000,- & $\begin{array}{l}\text { 77/Pid.sus/2013/PN.Sby, } \\
\text { January 6, } 2014\end{array}$ & $\begin{array}{l}\text { Jail } 1 \text { year } 3 \text { month fine } 50 \text { million } \\
\text { subsidiary } 3 \text { months confinement, } \\
\text { pay a replacement of Rp. } 32,000,000 \\
\text { subsidiary } 2 \text { months in prison }\end{array}$ \\
\hline 3 & $\begin{array}{l}\text { Corruption of BKD and } \\
\text { ADD funds from } \\
\text { Jambangan } \\
\text { Purwosari District, Kediri } \\
\text { Regency }\end{array}$ & Rp. 45.000.000,- & $\begin{array}{l}\text { 80/Pid.sus- } \\
\text { TPK/2016/PN.Sby, } \\
\text { November 7, } 2016\end{array}$ & $\begin{array}{l}\text { Jail } 1 \text { year } 3 \text { months, pay a } \\
\text { replacement money of Rp. } \\
30,500,000 \text {, subsidiary } 2 \text { months in } \\
\text { prison }\end{array}$ \\
\hline 4 & $\begin{array}{l}\text { Corruption ADD } \\
\text { village, District B } \\
\text { Kediri Regency }\end{array}$ & Rp. 14.842.350,- & $\begin{array}{l}\text { 117/Pid.sus/2010/PN.Kdi, } \\
\text { juny } 3,2010\end{array}$ & $\begin{array}{l}\text { Jail } 1 \text { year, pay a replacement money } \\
\text { of Rp. } 14,842,350,- \text { subsidiary } 1 \\
\text { month in prison }\end{array}$ \\
\hline
\end{tabular}

Source: the Supreme Court decision court

Table 2: Targets for recovery of TP losses. corruption which has a loss value of less than IDR 50,000,000

No. Case State Losses Fill in the Decision




\begin{tabular}{|c|c|c|c|}
\hline 1 & $\begin{array}{l}\text { Corruption ADD Krecek Village Badas } \\
\text { District, Kediri Regency }\end{array}$ & Rp. 14.161.400,- & $\begin{array}{l}\text { Jail } 1 \text { year fine of } 50 \text { million subsidiary } 1 \text { month } \\
\text { confinement, pay a replacement of Rp. } 4.245 .000 \text {, - } \\
\text { subsidiary of } 6 \text { months in prison }\end{array}$ \\
\hline 2 & $\begin{array}{l}\text { Corruption of Infrastructure Funds and } \\
\text { clean water infrastructure facilities in } \\
\text { Keling Village, Kapung District, Kediri } \\
\text { Regency }\end{array}$ & Rp.32.000.000,- & $\begin{array}{l}\text { Jail } 1 \text { year } 3 \text { month fine } 50 \text { million subsidiary } 3 \text { months } \\
\text { confinement, pay a replacement of Rp. } 32,000,000 \\
\text { subsidiary } 2 \text { months in prison }\end{array}$ \\
\hline 3 & $\begin{array}{l}\text { Corruption of BKD and ADD funds from } \\
\text { Jambangan Village, Purwosari District, } \\
\text { Kediri Regency }\end{array}$ & Rp. 45.000.000,- & $\begin{array}{l}\text { Jail } 1 \text { year } 3 \text { months, pay a replacement money of Rp. } \\
30,500,000 \text {, subsidiary } 2 \text { months in prison }\end{array}$ \\
\hline 4 & $\begin{array}{l}\text { Corruption ADD Maron village, District } \\
\text { B Tanya, Kediri Regency }\end{array}$ & Rp. 14.842.350,- & $\begin{array}{l}\text { Jail } 1 \text { year, pay a replacement money of Rp. } 14,842,350,- \\
\text { subsidiary } 1 \text { month in prison }\end{array}$ \\
\hline
\end{tabular}

Source: the Supreme Court decision court

The following is data on the implementation of court decisions against corruption with a loss of less than Rp 50,000,000 (fifty million rupiah) in the sampling case.

Table 3: Value of losses recovered through fines and pay compensation in the aftermath of the corruption case verdict the value of the loss is less than IDR 50,000,000

\begin{tabular}{llc}
\hline No. & Cases & State losses \\
\hline $\mathbf{1}$ & Corruption ADD Krecek Village Badas District, Kediri Regency & Rp. 14.161.400,- \\
\hline $\mathbf{2}$ & $\begin{array}{l}\text { Corruption of Infrastructure Funds and clean water infrastructure facilities in } \\
\text { Keling Village, Kapung District, Kediri Regency }\end{array}$ & Rp.32.000.000,- \\
\hline $\mathbf{3}$ & $\begin{array}{l}\text { Corruption of BKD and ADD funds from Jambangan Village, Purwosari } \\
\text { District, Kediri Regency }\end{array}$ & Rp. 45.000.000,- \\
\hline $\mathbf{4}$ & Corruption ADD Maron village, District B Tanya, Kediri Regency $0,-$ & Rp. 0,- \\
\hline
\end{tabular}

Source: the results of research analysis by the authors

Not achieving the recovery of state losses incurred state expenditure burdens:

- $\quad$ costs are not balanced with the value obtained by the state

- $\quad$ APH has not fully succeeded in confiscating the assets of the perpetrators to cover the obligation to pay replacement money.

- $\quad$ Not yet an asset data collection system. (asset tracking will require a high enough cost).

- The court's decision does not take into account the lost economic value as a relative risk of law enforcement, namely the effect of transaction costs arising in the legal implementation process from receipt of reports/complaints to the implementation of the judge's decision.

To analyze the economic value of law enforcement against corruption cases with losses of less than Rp 50,000,000 (fifty million rupiah), researchers compared the cost of detention of prisoners (the smallest budget item under investigation, ie Rp. 14,000/fourteen thousand rupiah) with the value of the recovered state loss, as follows:

1. ADD corruption case in Krecek Village, Badas Dstric, Kediri Regency

- $\quad$ the suspect/defendant is not detained so there is no detention fee.

- $\quad$ court ruling 1 year or 365 days in prison. (requires a meal fee of Rp. 14,000/day or Rp. 5.110,000/five million one hundred and ten thousand rupiah);

- The loss value of the BPKP audit result is Rp. fifty five thousand rupiah), and ordered the convicted person to replace it. This has been carried out by the convicted person.

- Taking into account the value of the loss in letter (c) and the cost of the convicted meal in letter (b), the fact is that the state has actually lost the economic value of Rp. 55,110,000 (fifty-five million one hundred and ten million rupiah). This value does not include investigation costs, investigation costs, prosecution costs, examination fees in court, and operational costs in correctional institutions as a relative risk of law enforcement. 
2. The corruption acceleration fund for the construction of clean water structures and facilities in Keling village, Kepung District, Kediri Regency.

- the process of investigation, prosecution and examination in court, the suspect/defendant is detained. The cost of detention for prisoners is $\operatorname{Rp} 4,298,000$ (four million two hundred ninety eight thousand rupiah).

- $\quad$ court decision 1 year 3 months imprisonment (455 days), the state incurs a cost of eating convicted IDR 14,000/day or IDR 6,370,000 (six million three hundred seventy thousand rupiah).

- The loss value of the BPKP audit was Rp 32,000,000 (thirty-two million rupiah), and the Panel of Judges stated in their decision that the state losses incurred were Rp 32,000,000 (thirty-two million rupiah), and ordered the convicted to replace it, but it was not carried out by the convicted person.

- $\quad$ Taking into account the value of the loss in letter (c) and the cost of the convicted meal in letters (a) and (b), the fact is that the state has not received a loss, but has instead lost the economic value of Rp. 93,50,000, - (ninety-three million and five hundred eight thousand rupiah). The above value does not include investigation costs, investigation costs, prosecution costs, examination fees in court, and operational costs in public institutions.

3. Corruption ADD Maron Village, B Tanya District, Kediri Regency.

- $\quad$ the investigation process was not carried out detention;

- At the prosecution and examination stage in court, the suspect/defendant is detained for 227 days at a detention detention fee of $\operatorname{Rp} 2,380,000$ (two million three hundred eighty thousand rupiah);

- The court's decision is 1 year (365 days). The state will pay a fee for convicted meals Rp 14,000/day or Rp 5.110,000 (five million one hundred and ten thousand rupiah);

- $\quad$ The loss value according to the BPKP audit result is Rp. 14,842,350 (fourteen million eight hundred forty-two thousand three hundred and fifty rupiah). The panel of judges stated in their decision that the perpetrators' actions caused state losses amounting to Rp 14,842,350 (fourteen million eight hundred forty-two thousand three hundred fifty rupiah), and ordered the convicted person to replace them, but were not carried out by the convicted person.

- $\quad$ Taking into account the value of the loss in letters (d) and the cost of the convicted meal in letters (b) and (c), the fact is that the state did not receive a refund, but instead lost the economic value of Rp. 22,752,350, - (twenty-two million seven hundred fifty-two thousand three hundred fifty rupiah). The above value does not include investigation costs, investigation costs, prosecution costs, examination fees in court, and operational costs in public institutions.

4. Corruption of BKD and ADD funds from Jambangan Village, Purwoasri District, Kediri Regency.

- $\quad$ During the investigation process, the investigator did not make an arrest;

- During the prosecution and examination process in court, the suspect/defendant is detained for 216 days with the cost of maintaining prisoner's care (harwat detainees) of Rp 3,024,000 (three million and twenty four thousand rupiah);

- The court's ruling is 1 year and 3 months in prison (455 days). The state will pay the cost of convicted meals Rp 14,000/day or $\operatorname{Rp~6,370,000~(six~million~three~hundred~seventy~thousand~rupiah);~}$

- The loss value according to the results of the BPKP audit is Rp. 45,000,000 (forty-five million rupiah). The judges in their decision stated that the perpetrators' actions caused state losses amounting to Rp 30,500,000 (thirty million five hundred thousand rupiah), and ordered the convicted person to replace them, but were not carried out by the convicted person.

- $\quad$ Taking into account the value of the loss in letters (d) and the cost of the convicted meal in letters (b) and (c), in the case the fact is obtained that the state did not receive compensation, but instead lost the economic value of Rp. 40,734,000.- (forty million seven hundred thirty four thousand rupiah). The above value does not include investigation costs, investigation costs, prosecution costs, examination fees in court, and operational costs in public institutions.

Considering the empirical data above, the economic value of law enforcement on criminal acts of corruption with a loss of less than $\mathrm{Rp} 50,000,000$ (fifty million rupiah) can be contributed in the reduction test of economic fundamentals as follows:

a. Test parameters for reducing rationality according to economic fundamentals

- $\quad$ ADD corruption case in Krecek Village, Badas Dstric, Kediri Regency.

If the judge's verdict on the case is analyzed economically, an illustration will be obtained that the effect of the cost of recovering state losses worth Rp4,245,000.- (four million two hundred forty-five thousand rupiahs) has not been comparable to the lost economic 
value. In this case the state actually lost a greater economic value, in the amount of Rp. 55,110,000 (fifty-five million one hundred and ten thousand rupiahs).

- The corruption acceleration fund for the construction of clean water structures and facilities in Keling village, Kepung District, Kediri Regency.

Judges' verdict on the case, if examined, has not yet contributed to the state as expected by the PTPK Law. To save the state loss of Rp. 32,000,000 (thirty-two million rupiahs) it actually resulted in a loss of economic value of Rp. 93,508,000.- (ninety-three million five hundred eight thousand rupiahs).

\section{- $\quad$ Corruption ADD Maron Village, B Tanya District, Kediri Regency.}

In law enforcement in this case the state has lost an economic value of Rp. 22,752,350 (twenty two million seven hundred fifty-two thousand three hundred and fifty rupiah), which is a value greater than the state loss of Rp. 14,842,350.- (fourteen million eight hundred forty-two thousand three hundred fifty thousand rupiah)

\section{- Corruption of BKD and ADD funds from Jambangan Village, Purwoasri District, Kediri Regency.}

Law enforcement in this case has resulted in the state losing an economic value of Rp. 45,000,000 (forty-five million rupiah), which is a greater value than the state loss which is the target of recovery, namely Rp. 83,634,000.- (eighty three million six hundred thirty four thousand rupiah).

Based on these calculations, it can be concluded that the final result of law enforcement against corruption cases with a loss value of less than Rp 50,000,000 (fifty million rupiah) in the case of the object of research, is only able to realize the goal of punishment as retribution (retribusionist), but fails in realizing the objectives of the PTPK Law namely recovery of state losses (recovery) and community protection (social defense). The absence of economic value from the implementation of the law will position law enforcement actions to be irrational according to the point of view of the intent and purpose of the establishment of the PTPK Law.

b. Option reduction test parameters according to economic fundamentals

Taking into account the cost of data that does not include the economic value of the state lost in law enforcement against criminal acts of corruption with losses of less than Rp 50,000,000 (fifty million rupiah) as described above, then law enforcement is an option that does not contribute to the state as the purpose and objectives of the establishment of the PTPK Law.

c. Value reduction test parameters according to economic fundamentals

Observing empirical facts and then carried out studies and analyzes with economic value variables, the recovery of state losses through law enforcement against criminal acts of corruption whose loss value is less than Rp 50,000,000 (fifty million rupiah) does not contribute economically to the country as intended and intended to establish the PTPK Law.

d. Parameters for the reduction of efficiency according to economic fundamentals

The economic value of law enforcement against corruption which has a loss value of less than Rp 50,000,000 (fifty million rupiah) if assessed in terms of efficiency for eradicating corruption, restoring state losses, or contributing to economic growth, the method of achieving goals through inefficient criminal law enforcement.

e. Utility reduction test parameters according to economic fundamentals

Taking into account the effects of transaction costs in law enforcement and the value of state losses that are targeted for recovery, the economic value of law enforcement against corruption has a loss of less than Rp 50,000,000 (fifty million rupiahs) not contributing to reducing crime corruption, does not recover state losses because the state is actually burdened with costs greater than the value of the losses to be recovered, and is not able to realize high efficiency in the context of economic growth. In other words, restitution of losses through enforcement of criminal law against acts of corruption whose losses are less than Rp. 50,000,000 (fifty million rupiah) in a utility value that is expected to not achieve the PTPK Law.

f. Reduction test parameters for game theory according to economic fundamentals.

Noting the empirical data as described above, the tendency of the perpetrators not to pay fines, not to pay replacement money and choose to serve a sentence of imprisonment/substitute prison because it is economically more favorable for the convicted person. In game theory, the choice to recover state losses, eradicate corruption, and realize high efficiency in order to create economic growth, through the enforcement of criminal law is an unfavorable strategy because it does not provide economic contribution to the country as expected by the establishment of the PTPK Law.

g. Test parameter reduction in transaction costs according to economic fundamentals.

Taking into account the effects of transaction costs as the data described above, the economic value in reducing the cost of economic fundamental transactions to law enforcement of corruption which has a loss value of less than Rp 50,000,000 (fifty million rupiah), 
is an option to pay a decision inaccurate because it does not contribute to economic development as expected by the establishment of the PTPK Law.

Empirical facts that have been analyzed based on aspects of rationality, choice, value (efficiency), efficiency, utility, game theory and transaction costs, if an assessment is conducted according to the purpose of the establishment of the PTPK Law, then the reality will be obtained that there is no interaction between law enforcement towards criminal acts of corruption whose loss value is less than Rp 50,000,000 (fifty million rupiah) with the aim of establishing the PTPK Law in national economic development, as follows:

- $\quad$ The purpose of the establishment of the PTPK Law is to eradicate corruption, recover state losses, and high efficiency in order to realize economic growth and national development;

- Criminal sanctions in the PTPK Law when viewed from an analysis of economics are to realize efficiency that is relevant to achieving legal objectives with low social costs;

- The implementation of the PTPK Law by economic analysis is expected to stimulate government policies in the context of equitable distribution of income and social welfare

Law enforcement against corruption which has a loss of less than Rp 50,000,000 (fifty million rupiah), which does not contribute to the country's economy and instead adds to the burden of state expenditure, is an act that has the potential to cause leakage of state money through the law enforcement sector. Such law enforcement has no economic value to the country and tends to disrupt economic stability.

\section{Conclusions}

The PTPK Law was made for economic stability therefore the solution to the problem of corruption cannot be separated from the consideration of the country's economy, and the costs that pose a relative risk to state expenditure affecting the country's economy. Juridical reality, the regulation of additional criminal charges, namely the penalty of paying as much as the amount of corrupt compensation as stated in Article 18 paragraph 1 letter (b) of the PTPK Law, if it is related to empirical facts about the imbalance between costs and the recovered economic value, is the reality is that the series of state expenses has increased. If the final result of law enforcement against corruption does not have an economic contribution to the state, then the law enforcement does not realize the essence of punishment and does not protect the values to be protected by the PTPK Law.

Resolving criminal acts of corruption with an economic approach in the future needs to consider the following aspects, among them Cost efficiency law enforcement costs affect the economy and welfare. Therefore law enforcement against corruption must consider an economic analysis framework to maintain economic development stability; Consequently, law enforcement is not just for justice, certainty and benefit, but must be able to realize public welfare as mandated by the constitution; and The values that the PTPK Law intends to protect are to eradicate corruption, recover state losses and create high efficiency in the context of realizing economic growth and national development.

\section{References}

Fajar, Sugiyanto. (2013). Economic Approach To Law. Jakarta, PT Kencana Prenada Media Group.

Hunt, Alan. (1986). The Theory of Critical Lega Studies. Oxford Journal of legal strudies. 6(1), 1-45. https://doi.org/10.1093/ojls/6.1.1

John, Kenedi. (2017). Kebijakan Hukum Pidana (Penal Policy) Dalam Sistem Penegakan Hukum Di Indonesia. Yogyakarta, pustaka pelajar.

Karl E. Case and Ray C. Fair. (1999). Prinsip-Prinsip Ekonomi. edisi ke delapan. Jakarta. Erlangga.

Louis, Kaplow and Steven, Shavel. (2002). 'Economic Analysis Of Law'. Harvard Law School And Nastional Bureau Of Economic Reseach. Handbook Of Public Economics. 3. edited by A.J. Aurbach and M. Feldstein.

Suparmoko. (1992). Keuangan Negara Dalam Teori Dan Praktek. Yogyakarta, BPFE.

Nazaruddin, lathif. (2017). 'Teori Hukum Sebagai Sarana /Alat Untuk Memperbaharui Atau Merekayasa Masyarakat'. Journal of Pakuan Law Review. 3(1): 76-77. DOI: 10.33751/palar.v3i1.402.

Romli atmasasmita.(2018). Rekonstruksi Asas Tiada Pidana Tanpa Kesalahan - Geen Straf Zonder Schuld. Jakarta, PT Gramedia Pustaka Utama.

Sadono sukirno. (2009). Mikro Ekonomi-Teori Pengantar. edisi ke tiga. Jakarta, PT RadjaGrafindo.

T.J. Gunawan. (2018). Konsep Pemidanaan Berbasis Nilai Kerugian. revision edition. Jakarta, Kencana.

https://kbbi.web.id/rasional.html

presidenri.go.id

Laws And Regulations

Indonesia, (1945), the Constitution of the Republic of Indonesia, 1945.

Indonesia, (2003), Law Number 17 of 2003 concerning State Finance.

Indonesia, (2004), Presidential Instruction number 5 of 2004 concerning the acceleration of corruption eradication.

Indonesia, (2006), Law No. 7 of 2006 concerning the ratification of the UN anti-corruption convention. 
Indonesia, (2010), Decision of the Kediri District Court Number: 117 / Pid.sus / 2013 / PN.Kdi, dated June 13, 2010.

Indonesia, (2011), Surabaya District Court Decision number: 151 / Pid.sus / 2011 / PT Sby, March 29, 2011.

Indonesia, (2011), Surabaya District Court Decision number: 92 / Pid.sus / 2016 / PT Sby, December 5, 2011Indonesia, (2011), Presidential Instruction number 9 of 2011 concerning the 2011 corruption prevention and eradication action plan.

Indonesia, (2014), Decision of the Supreme Court of the Republic of Indonesia Number: 111 / PK / Pidsus / 2013 dated December $17,2014$.

Indonesia, (2014), Surabaya District Court Decision number: 73 / Pid.sus / 2013 / PN.Sby, January 6, 2014. 